\title{
Seasonal and inter-annual ONSET Sea Surface Temperature variability along the northern coast of the Gulf of Guinea
}

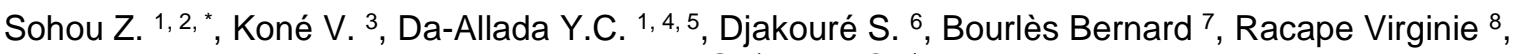
Degbe G. ${ }^{1}$, Adje C. ${ }^{1}$

${ }^{1}$ Institut de Recherches Halieutiques et Océanologiques du Bénin (IRHOB/CBRSI), Benin

2 Département Zoologie, Faculté des Sciences et Techniques (FAST/UAC), Benin

${ }^{3}$ Centre de Recherches Océanologiques de Côte-d'Ivoire (CRO), 29, Rue des Pêcheurs, BPV 18,

Abidjan, Cote d'Ivoire

${ }^{4}$ ENSTP/UNSTIM, Abomey, Benin

5 ICPMA-UNESCO Chair/UAC, Cotonou, Benin

${ }^{6}$ Laboratoire de Physique de l'Atmosphère et de Mécanique des Fluides (LAPA-MF), UFR SSMT,

Université Félix Houphouët-Boigny, Abidjan, Cote d'Ivoire

7 IRD/IMAGO, Centre IRD de Bretagne, Technopole Pointe du Diable, Plouzané, France

${ }^{8} \mathrm{CNRS} / \mathrm{CORIOLIS}$, Plouzané, France

*Corresponding author : Z. Sohou, email addresses : zsohou@yahoo.fr ; zsohou@gmail.com

\begin{abstract}
:
The aim of this study is to characterize the coastal upwelling variability at seasonal and inter-annual time scales in the northern Gulf of Guinea (NGoG) using Sea Surface Temperature (SST) collected with autonomous "ONSET" thermometers. Results show that the ONSET SST data are suitable for numerical model evaluation, and provide relevant information in addition to satellite and reanalysis data at seasonal cycle. The minor and major coastal upwellings are present in all the products. The inter-annual SST variability is more pronounced in the western part of the region (Côte d'Ivoire and Ghana) than in the eastern part (Benin and Nigeria). The pattern differences between the west and the east of the region highlight a large spatial variability of the SST in the NGoG. Indeed, the signal of the minor upwelling season is visible only in the west of the basin, namely between Cape Palmas and Cape Three Points. We also observe a well-established thermal gradient between the western and eastern parts of the basin. This gradient is increasing from west to east during the major upwelling season, and decreasing from east to west during the rest of the year. The coastal ONSET data allow to evidence higher SST anomalies than those deduced from satellite and reanalysis products. Although the cold or warm events observed in 2008, 2010 and 2012 are well detected by all products, only the ONSET data set reveal the strong negative SST anomaly observed in 2009 along the coast of Ghana and Côte d'Ivoire.
\end{abstract}

Keywords : Sea Surface Temperature, ONSET data, Gulf of Guinea, coastal upwelling, seasonal variability, inter-annual variability 


\section{Introduction}

Temperature is an essential parameter for the study and the monitoring of marine ecosystems. To understand an event, or to analyze the health of an ecosystem, it is essential to know the history of the physicochemical conditions of the environment such as temperature. To characterize the coastal upwelling in the northern Gulf of Guinea (NGoG), sea surface temperature (SST) is the main parameter relatively easy to measure. Coastal upwellings in the NGoG have a mostly seasonal development (Hardman-Mountford and McGlade, 2003). However, their occurrence and amplitude are also subject to inter-annual variations that may affect the onset and the intensity of the west African monsoon (Lamb, 1972; Lamb and Peppler 1992; Fontaine and Janicot, 1996; Vizy and Cook, 2001; Marin et al., 2009; Brandt et al., 2011) as well as primary production and resources (e.g. Binet and Marchal, 1993; Koné et al., 2017). SST variability in the NGoG is complex and depends upon several processes: it is strongly conditioned by horizontal and vertical advection, equatorial dynamics (waves and upwelling), by mixtures at the atmosphere-ocean interface (Jouanno et al., 2011) and by nonlinear dynamics, advection of vorticity and topographic variations (Djakouré et al., 2017). The SST inter-annual variability in the Gulf of Guinea is also associated with the Pacific El Niño and La Niña inter-annual variabilities (e.g. Burls et al., 2011; Toualy et al., 2012).

In situ coastal temperature data obtained regularly and maintained over the long term are a very useful complement for satellite data analysis, numerical models validation and for SST variability analysis. In the framework of the analysis and the monitoring of ocean surface conditions in the NGoG, a network of coastal SST measurements has been implemented and maintained from 2005 to 2008 as part of the regional programs "Research Program in Physical Oceanography in West Africa (PROPAO; 2007-2010)" and" Coastal, Oceanic and Climatic Analyses in the North of the Gulf of Guinea (ALOC-GG: 2010-2013)" (Sohou et al., 2014). This network extends along the coastline from Côte d'Ivoire to Nigeria, except Togo 
(Figure 1). These coastal network SST measurements are crucial for characterizing IvorianGhanaian upwelling and for feeding regional databases that can be used by the entire scientific community.

Kouadio et al., (2013) analysed the date of the onset and of the end of the boreal summer coastal upwelling event. These authors used the PROPAO network data and the satellite SST derived from the Tropical Rainfall Measuring Mission (TRMM) Microwave Imager (TMI). This work suggested that there are different areas for the coastal upwelling formation and that no significant trend is observed between the beginning and the end of the upwelling.

To complete the analysis of Kouadio et al., (2013), we address in this study, at first, the analysis of SST seasonal variability, and secondly its inter-annual variability. For this purpose, we compare the in situ ONSET data to satellite products. In addition, we use the ONSET data to evaluate the regional model output. These results are then be discussed.

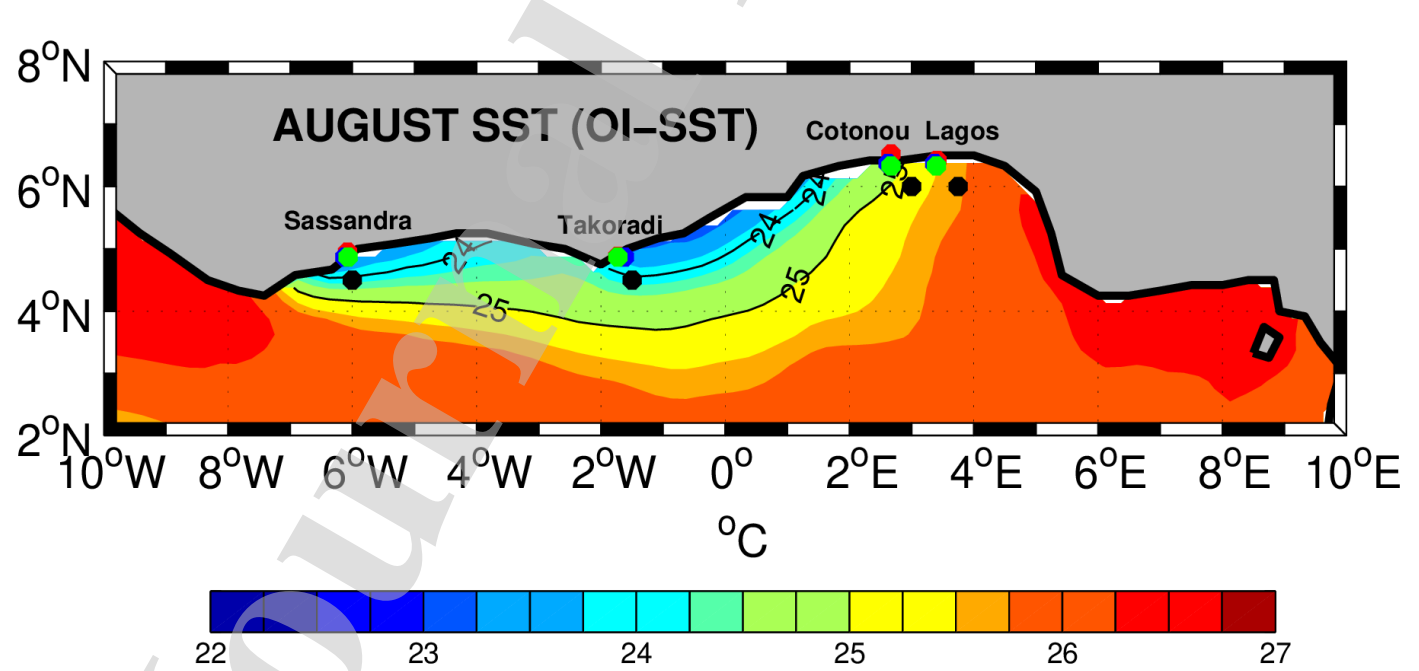

Figure 1: Satellite SST distribution during August (colour shading) and location of SST data used in this study. The red dots represent the position of the PROPAO network ONSET thermometers deployed along the coast at Sassandra, Takoradi, Cotonou and Lagos. The green, blue and black dots represent the corresponding closest points to the ONSET positions of the ROMS model grid, OI-SST and ERAI, respectively. 


\section{Material and methods}

\subsection{Thermometers}

The ONSET temperature sensors consist of several successive models used since 2005 (StowAway model, then Optic StowAway and finally Hobo-UTBI001 TidbiT) and are all type 5 TIDBIT sensors, version 2 with a temperature range from $-20{ }^{\circ} \mathrm{C}$ to $+50{ }^{\circ} \mathrm{C}$ with an accuracy of $\pm 0.2{ }^{\circ} \mathrm{C}$ between 0 and $50^{\circ} \mathrm{C}$, resolution 12 bits 0.02 at $25^{\circ} \mathrm{C}$. (Fig. 2). These sensors were initially calibrated at the French Institute for Research and Exploitation of the Sea (IFREMER) in Brest. Since 2010, the sensors have been calibrated at the Fisheries and Oceans Research Institute of Benin (IRHOB, Cotonou, Benin) using a JULABO ED5A / B thermostatic bath.

The ONSET sensors are accompanied by a software "HOBOW are Pro version 3.4.1" for downloading, reading data and getting started. The chosen frequency of data recording is one (01) hour for all PROPAO partner countries, namely and initially Nigeria, Benin, Ghana and Côte d'Ivoire. The Table (1) provides the coordinates of the different ONSET stations.

Coastal SST data from the various member countries of the network are gathered in a PROPAO regional database, maintained at IRHOB. The data are validated and archived on the PROPAO web page (http://nodcbenin.odinafrica.org/images/Documents/PROPAO/Banque_Donnees/Cotier/Benin/Cotonou/C otonou_10_12_2010_en_forme.txt). The length of data series varies according to the beginning of the program in the different countries. The ONSET thermometers were first deployed in Cotonou (Benin) in 2005, then in 2008 for the other stations (Sassandra, Takoradi and Lagos). Sensors are serviced about every three to four months in all countries. However, it may happen that some countries do not follow this periodicity due to certain constraints (climatic hazards, storms, vandalism, etc.) in the field. 
a)

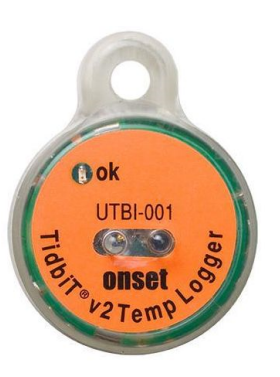

b)

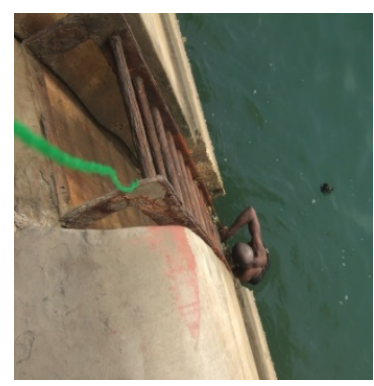

c)



Figure 2: a) ONSET TIDBIT v2 sensor, b) Sensor Immersion site at the port of Cotonou, C) Interface for reading and retrieving data

The sensors are used in duplicate to compare the data in order to limit the drifts or the risks of failure and thus to ensure a reliable time series.

The data calibration and validation consists on a correction of the data set by a calibration polynomial (equation 1) specific to each sensor or to each event.

$y=a x_{6}+b x_{5}+c x_{4}+d x_{8}+e x_{2}+f x+g\left(\mathbb{E} q_{1}, 1\right)$

There are two possibilities:

The sensor is not calibrated before use; the calibration polynomial is therefore deduced by comparing the SST measurements recorded by the ONSET thermometer with the measurements obtained with an independent thermometer via a linear least squares regression of the $\mathrm{Ax}+\mathrm{B}$ form. This 1 degree polynomial is then applied to the data set acquired by the sensor during an immersion by replacing in the equation 1 : $\mathrm{f}$ by $\mathrm{A}, \mathrm{x}$ by the raw SST data, $\mathrm{g}$ by $\mathrm{B}$ and $\mathrm{a} / \mathrm{b} / \mathrm{c} / \mathrm{d} / \mathrm{e}$ by 0 . We then obtain equation 2 :

correctedSSTdata $=A *$ rawSSTdata $+B\left(\mathbb{E} \mathrm{q}_{1}, 2\right)$

If the sensor has been calibrated before use, the polynomial of degree 1 to 6 is then 
deduced and applied to the corresponding data set by replacing $\mathrm{x}$ in the equation 1 by the raw SST data and the coefficients from a to $g$ by those established during calibration or by 0 .

Step $\mathrm{N}^{\circ} 1$ : Fill in the form 'Events capture'

An 'Events capture' entry sheet must be filled in for each raw SST data file sent by the partners $(1$ file $=1$ sensor immersed during a given period $)$. As a first step, this sheet is filled from the associated TIDBIT ONSET thermometer tracking sheet.

Sensor monitoring sheets are filled each time when the sensor is deployed or retrieved from the water, in order to well monitor each sensor (status, batteries, calibration etc.). These different pieces of information make it possible to detect possible errors in the data. "Quality Codes" are assigned to the different data according to the World Ocean Circulation Experiment (WOCE) standards.

It should be noted that the ONSET sensor data series are regularly updated, according to raw data availability in the different member countries. Only some series of validated data from Benin, Nigeria and Côte d'Ivoire are included in the PROPAO data web page. While waiting to secure the validated data on the web page, we have just metadata that requires the data requesters to directly contact IRHOB web page manager to be satisfied.

\subsection{ONSET sensor data analyse}

To analyse the ONSET sensor data series, we used several SST data sets derived from satellite, reanalysis data and model outputs.

The Monthly SST data from the National Oceanic and Atmospheric Administration (NOAA) Optimum Interpolation SST (OI-SST) with a horizontal resolution of $1 / 4^{\circ}$ are used. OI-SST (Reynolds et al., 2002) data are a blend of satellite and in situ observations and available from 1982 to present. We also use the SST ERA-Interim (ERAI) reanalysis monthly 
data provided by the European Centre for Medium-Range Weather Forecasts (ECMWF) (Dee et $a l ., 2011$ ). ERAI product is available at $0.75^{\circ}$ resolution and from 1979 to present.

The numerical model outputs are derived from a two-way nested configuration of the Regional Oceanic Modelling System (ROMS) (Shchepetkin and McWilliams, 2005, Debreu et al., 2012). The model surface wind stress is derived from the National Centers for Environmental Prediction (NCEP Climate Forecast System Reanalysis), CFSR re-analysis (Saha et al., 2010). The lateral boundary conditions are extracted from the Simple Ocean Data Assimilation (SODA) (Carton and Giese, 2008). The model configuration is built over the Tropical Atlantic with a nested focusing on the Gulf of Guinea. It was run over years 1979 to 2008. A more complete description and evaluation of the configuration are given by Djakouré et al. $(2014,2017)$.

\section{Results}

\subsection{SST seasonal variability}

\subsubsection{ONSET data, satellite and reanalysis products (OI-SST and ERAI)}

In this section, we present the seasonal variability of SST within the PROPAO network countries from Nigeria to Côte d'Ivoire (Figure 3).

In Lagos (Nigeria), the averaged thermal features obtained from 2008 to 2012 derived from the ONSET thermometers show relatively strong seasonal fluctuation (Figure 3a). SST increases from January to May with a peak of about $30^{\circ} \mathrm{C}$. Then, we observe a cooling from June to September with a minimum of $26.5^{\circ} \mathrm{C}$ occurring in August. After this cooling, SST increases reaching a maximum of $29^{\circ} \mathrm{C}$ in November-December. This feature is the same displayed by both satellite and reanalysis data (OI-SST and ERAI), respectively (Figure 3a). Note that, the ONSET SST values are quite greater than those given by both satellite and reanalysis data sets. The RMS value derived from the ONSET data is $28.89^{\circ} \mathrm{C}$, while it is 
$28.10^{\circ} \mathrm{C}$ and $27.98^{\circ} \mathrm{C}$ in both ERAI and OI-SST data, respectively (Table 2).

In Cotonou (Benin), the SST temporal evolution is similar than that displayed in Lagos (Figure 3b). Indeed, we observe an increase from January to May with a peak of $29.8^{\circ} \mathrm{C}$, and a cooling from June to August with a minimum of $25^{\circ} \mathrm{C}$. The SST values derived from the ONSET thermometers are very close to those derived from both ERAI and OI-SST, consistent with the RMS values of $28.06^{\circ} \mathrm{C}, 27.98^{\circ} \mathrm{C}$ and $27.78^{\circ} \mathrm{C}$, respectively (Table 2).

In Takoradi (Ghana), the SST seasonal variability is strongly marked, with an increase of temperature from January to May with a peak of $28^{\circ} \mathrm{C}$, followed by a strong cooling from June to September with a minimum of $21.8^{\circ} \mathrm{C}$ in August. After this minimum, SST increases again from October to December. Despite this feature displayed by both satellite and reanalysis data is the same, $\mathrm{SST}$ values derived from these latter are greater $\left(24^{\circ} \mathrm{C}\right)$ than those derived from ONSET thermometers. As shown in the Table 2, the RMS of SST derived from the ONSET data $\left(26.20^{\circ} \mathrm{C}\right)$ is lower than those of both the satellite $\left(27.35^{\circ} \mathrm{C}\right)$ and reanalysis (26.96) data.

At Sassandra (Côte d'Ivoire), the averaged SST patterns show strong seasonal fluctuations (Figure 3d). The temporal evolution of the SST shows a moderate cooling from January to March, with values around $27^{\circ} \mathrm{C}$. Then SST values increase until May reaching a peak of $28^{\circ} \mathrm{C}$. After this warm event, we observe a strong cooling from June to September with a minimum of $21^{\circ} \mathrm{C}$ during August and September. This cooling is more pronounced at Sassandra than at other sites (Takoradi, Cotonou and Lagos). Here also, SST values derived from the ONSET thermometers are weaker than those of both satellite and reanalysis data sets $\left(24^{\circ} \mathrm{C}\right)$, consistent with the $\mathrm{RMS}$ values $\left(25.89^{\circ} \mathrm{C}, 26.75^{\circ} \mathrm{C}\right.$ and $\left.27.29^{\circ} \mathrm{C}\right)$, respectively. 

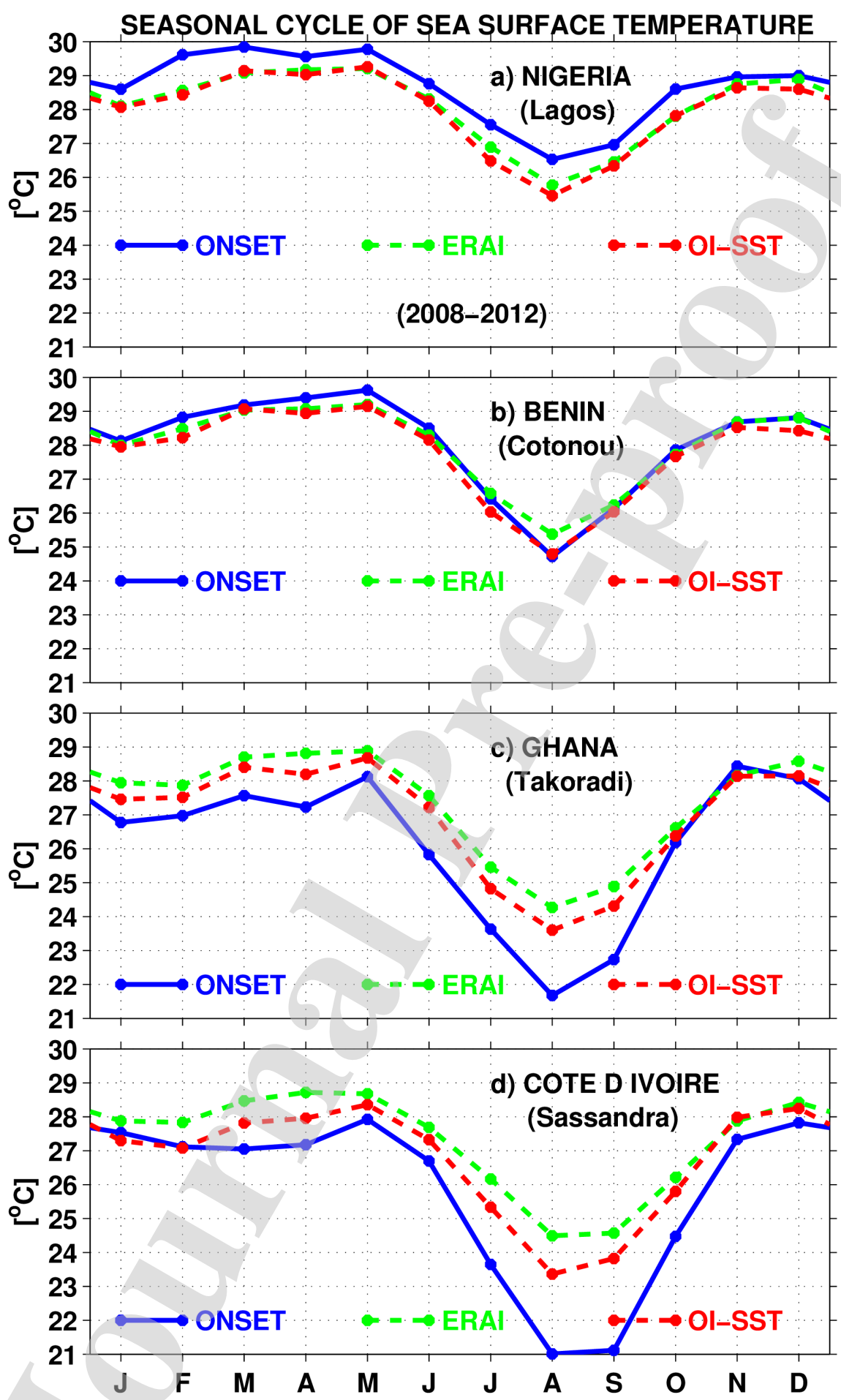

Figure 3: Monthly evolution of SST averaged from 2008 to 2012 as obtained from ONSET sensors, ERAI and OI-SST along the coast of the PROPAO network countries, i.e. in Nigeria (a), Benin (b), Ghana (c) and Côte d'Ivoire (d). 


\subsubsection{Evaluation of the ROMS Model}

In this section, we compare the seasonal variability of SST derived from the ROMS model to satellite (OI-SST), reanalysis (ERAI) and in situ ONSET data averaged from 2005 to 2008.

In Lagos (Figure 4a), the SST derived from the ROMS model shows a strong seasonal fluctuation with an increase from January to May and a cooling from June to August where SST reaches its minimum $\left(\sim 27^{\circ} \mathrm{C}\right)$ in August. The model simulates a second increase from September to December where it reaches $29^{\circ} \mathrm{C}$. The patterns displayed here are consistent with ERAI and OI-SST data and are quite the same as those shown in Figure (3a).

In Cotonou (Figure 4b), the seasonal cycle of SST displayed by the model shows the same patterns as in Figure (3b) and are similar to those in Lagos. The cooling during the major upwelling period is more pronounced than the Lagos one, with a minimum of $26^{\circ} \mathrm{C}$ in August. This is consistent with the in situ ONSET data and both in the ERAI and OI-SST data; even if the cooling in the latter is more pronounced (the minimum is less than $26^{\circ} \mathrm{C}$ ).

In Takoradi (Figure 4c), the SST seasonal cycle displayed by the ROMS model shows a strong seasonal variation, with an increase from January to May where it reaches a maximum of $28^{\circ} \mathrm{C}$, followed by a strong cooling from June to September with a minimum of $24.8^{\circ} \mathrm{C}$ in August. Then, the model simulates a second SST increase from October to December. These patterns are quite the same as those in Figure (3c). The minimum simulated during the major upwelling period is rigorously the same as the one derived from ERAI, and it is greater than the value $\left(24^{\circ} \mathrm{C}\right)$ derived from OI-SST data.

In Sassandra (Figure 4d), the model simulates the same SST seasonal patterns as in Takoradi, with the same range of SST minimum $\left(25^{\circ} \mathrm{C}\right)$ during the major upwelling period. The patterns simulated by the model is also consistent with those of the satellite and 
reanalysis products, even if the cooling from OI-SST data is more pronounced than from both the ROMS model and ERAI data. The cooling in Sassandra and Takoradi is stronger than the cooling in Cotonou and Lagos.
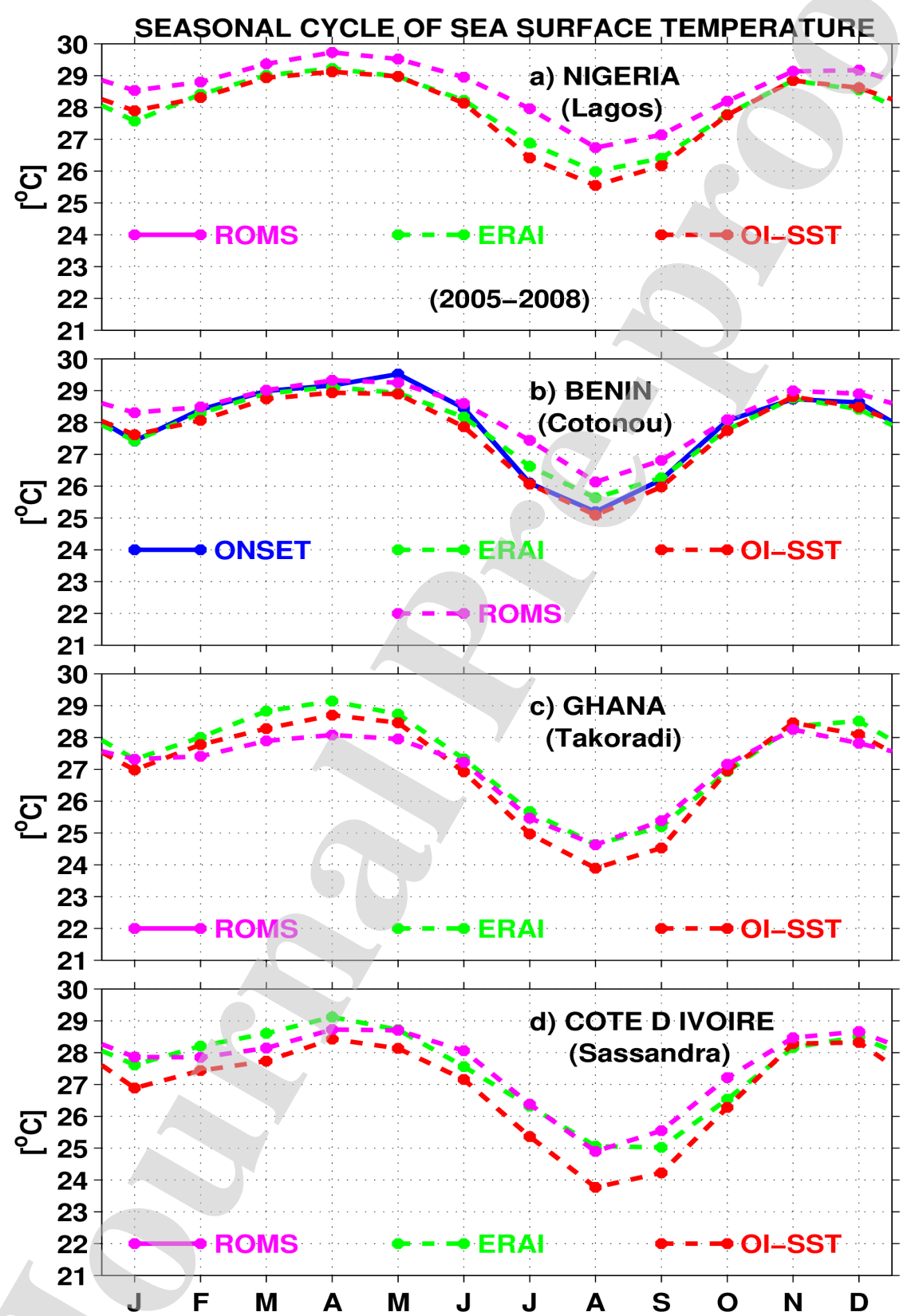

Figure 4: Monthly evolution of SST averaged from 2005 to 2008 as obtained from ONSET sensors, ERAI and OI-SST in the countries of the PROPAO network, i.e. in Nigeria (a), Benin 
(b), Ghana (c) and Côte d'Ivoire (d). Note that the ONSET SST data are only available at Cotonou during the above-mentioned period.

\subsection{SST inter-annual anomalies variability}

The temporal evolutions of the SST inter-annual anomalies (SSTA) along the coast of the PROPAO network countries are shown in Figure (5). The temporal SSTA evolution shows episodes of warm (positive anomaly) and cold (negative anomaly) SST episodes.

In Lagos (Nigeria) and Cotonou (Benin), the SST inter-annual variability presents small variations except in 2010 when SSTA are strongly positive all along the year with values around $+0.5{ }^{\circ} \mathrm{C}$ for ERAI product and slightly lower with OI-SST data (Figure 5a and b). In contrast to the stations of Nigeria and Benin, the inter-annual SST variability at the Ghanaian (Takoradi) and the Ivorian (Sassandra) continental shelves are well marked, with a strong SST fluctuation (Figure. 5c and d). In these countries, SST variabilities show a large negative (less than $-0.5^{\circ} \mathrm{C}$ with ONSET data) anomalies during 2009 and 2012 (cold years), while in 2010 , the SSTA remained positive (higher than $+0.5^{\circ} \mathrm{C}$ from ONSET data). Note that the ONSET data indicate more important SSTA than ERAI and OI-SST products (for example, in Ghana, SSTA reaches $+1{ }^{\circ} \mathrm{C}$ with ONSET data whereas it is $+0.5^{\circ} \mathrm{C}$ in ERAI and OI-SST products in the warm year 2010). The SSTA at Sassandra (Côte d'Ivoire) also exhibits a warming (around $+0.5^{\circ} \mathrm{C}$ ) in the second half of the year 2008 .

The SST inter-annual signal displayed by the Figure A1 in Appendix A is the same as those displayed by the Figure 5, even if the amplitude of the anomalies is higher than in the latter. 

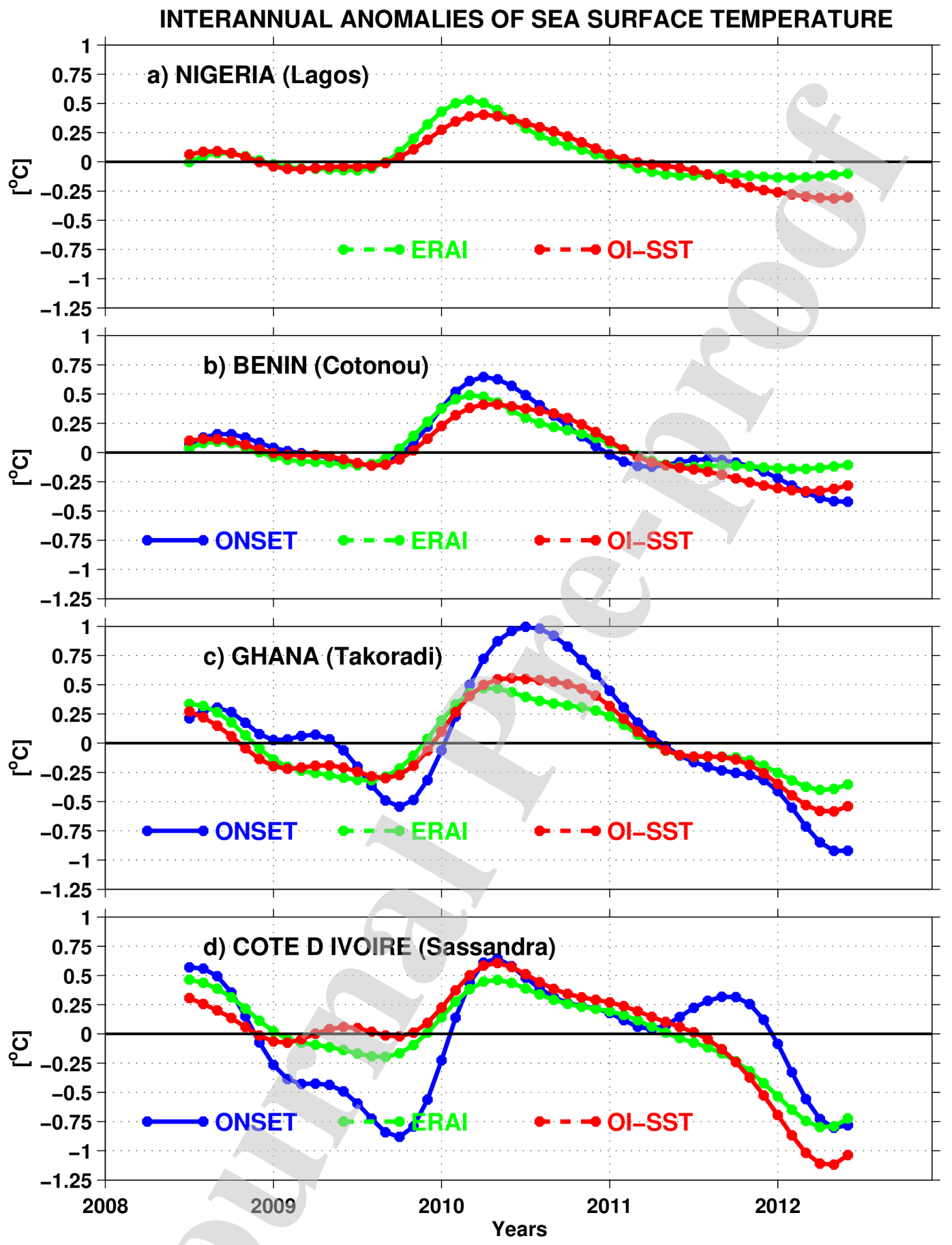

Figure 5: Inter-annual anomalies of SST in the countries of the PROPAO network. To obtain the inter-annual anomalies, the monthly seasonal climatology of SST is removed from the signal. 


\section{Discussion and Conclusion}

The seasonal and the inter-annual variabilities of SST along the coast of the NGoG are studied by using the PROPAO ONSET network in situ data. SST Seasonal variability shows two distinct upwelling seasons. A minor upwelling season that usually takes place between January and March, and the major upwelling season that takes place between July and September. The seasonal pattern derived from our ONSET observations is consistent with previous results obtained elsewhere (Bakun, 1978; Verstraete, 1992; Hardman-Mountford and McGlade, 2003). Morlière (1970), Arfi et al. (1993), and Colin et al. (1993) also described the same marine seasons, with a minor and a major upwelling seasons. This seasonal variability is well pronounced along the coast, from Côte d'Ivoire to Nigeria. During the major upwelling period, the mean SST is around $21^{\circ} \mathrm{C}$ in Sassandra and $22^{\circ} \mathrm{C}$ in Takoradi, showing that the upwelling intensity is stronger in the former than in the latter, in agreement with the study of Dermarcq and Aman (2002). Between these two upwelling seasons, we observe relaxation phases when the SST increases. These include the period of April-June and OctoberDecember. These results are supported by the work of Djakouré et al., $(2014,2017)$ and Koné et al., (2017) who described the same patterns. The SST seasonal variability in the NGoG region is found to be related to the nonlinear dynamics of the Guinea Current, the topographic variations and the advective terms effects, from Cape Palmas near Sassandra, to Cape Three Points, near Takoradi. From Cape Three Points to Cotonou and Lagos, the SST seasonal variability is principally induced by local winds (Djakouré et al., 2017).

It should be mentioned that the minor upwelling is mainly visible in the western part of the network (i.e. in Sassandra and to a lesser extent in Takoradi), consistent with the study of Demarcq and Aman (2002). According to these authors, the minor upwelling signature in Ghana is an extension of that of Côte d'Ivoire since its spatial signature does not affect the eastern part of Ghana. In addition, the cooling in the western region (Sassandra and Takoradi) 
is more marked than in the eastern region (Cotonou and Lagos). This is in agreement with the work of Morlière and Rebert, (1972), and Colin (1989) who described similar pattern. On one hand, the difference between the ONSET SST values and those of satellite and reanalyses could be due to the distance between the ONSET sensors locations and the satellite/reanalyses grid points. Indeed, as mentioned in Table 1, the distance between the ONSET point with the nearest satellite (OI-SST) and reanalyses (ERAI) grid point is $7-10 \mathrm{~km}$, and $49-68 \mathrm{~km}$, respectively. In their study, Manyilizu et al., (2014) also highlighted similar differences between in situ temperature data and satellite data (AVHRR, TMI) due to coastal position of the stations. On the other hand, as stated by Alvera-Azcàrate et al. (2011), the comparison of satellite infrared data with in situ data is limited by the presence of clouds in the atmosphere, which prevents the infrared radiation from the sea surface to reach the satellite. The presence or absence of clouds influences the SST. This may specially affect the bias between in situ and satellite data. According to Hardman-Mountford and McGlade (2003), the NGoG region has particularly high cloud cover and high levels of atmospheric water vapour content, which can influence the accuracy of satellite-borne radiometers. In addition, the reanalyses (ERAI) product consists in coupling atmospheric model to ocean-wave model that could also explain the reanalyses data differ from in situ measurement.

The comparison between the ONSET SST data and ROMS model outputs at Cotonou station shows that these data are suitable for model validation, and appear as a good complement to satellite and reanalysis data.

The inter-annual SST variability is well pronounced in Côte d'Ivoire and Ghana. In Côte d'Ivoire, the SSTA during the boreal winter (minor upwelling season) are greater than those recorded during the boreal summer (major upwelling season, Figure A2 d); thus the inter-annual variability is more marked during the minor upwelling season than during the major season. These results confirm those by Colin et al. (1993), who studied the inter-annual 
variability of temperature during the period 1967-1985 in Abidjan, and noted a strong interannual variability during the boreal winter. In Ghana, the opposite situation occurs. Indeed, the thermal differences are greater during the major upwelling season than those observed during the minor one (Figure A2 c). This means that the SST inter-annual variability is greater during the major upwelling season than during the minor one over the period of our study. SSTA cycle displayed during the major upwelling period differ from Ghana to Côte d'Ivoire (Figure A2c and d), inducing that the upwelling dynamic in the two regions differ. Djakouré et al. (2017) have pointed out that the upwelling in the vicinity of Cape three Points is winddriven, while it is Current-driven in Cape Palmas. Going further to the East (Benin and Nigeria), the SST inter-annual variability is less pronounced (A2 a and b). Thermal amplitudes remain moderate compared to those recorded in the West (Côte d'Ivoire and Ghana).

It should be noted that the years 2009 and 2012 are characterized by strong cold SSTA in Côte d'Ivoire and Ghana, with a particularly cold event in 2009 in Côte d'Ivoire during the major upwelling season that extends until October, in opposite to the classic years when it stops in September. Note that the strong cold SSTA in 2009 was only observed from ONSET data in Côte d'Ivoire and was not detected by the other products. This illustrates the relevance of ONSET data for studying SST variability in the NGoG. All these cold events could be linked to inter-annual climatic modes. For instance, it has been recently shown that the 2009 and 2012 years were characterized by the appearance of the Atlantic meridional mode events (Awo et al., 2018). The strong cold anomalies in 2012 may have been related to the North Atlantic Oscillation (NAO) positive phase of 2012.

The years 2008 and 2010 are marked by warm anomalies, largest in the west. These differences in patterns between the west and the east of the basin highlight a large spatial SST variability in the NGoG. Indeed, the signal of the minor upwelling season is visible only in 
the west of the basin, namely between Cape Palmas and Cape Three Points (Arfi et al., 1993; Djakouré et al., 2017). In addition, we also observe a well-established thermal gradient between the western and eastern parts of the basin. This gradient is increasing from west to east during the major upwelling season, and decreasing from east to west during the rest of the year. According to Wauthy (1983), the influence of the Gulf of Guinea is decisive at the regional scale on the climate of the coastal strip. Contrary to the regulatory role played by the thermal regime in the temperate latitudes, the ocean of this equatorial region can exacerbate the annual air thermal amplitude of certain localities where coastal upwellings are responsible for well-marked cold seasons, as observed in Côte d'Ivoire and Ghana.

The high SST anomalies depicted in 2010 from Nigeria to Côte d'Ivoire, both from the PROPAO network data and the satellite products, are in agreement with the high positive SSTA observed in 2010 over the whole Atlantic basin. These strong high positive anomalies have been found to be acted with the anomalously high positive Atlantic Multi-decadal Oscillation (AMO) and negative NAO of the year 2010 (Lefèvre et al., 2013; Servain et al., 2014). The study of Lefèvre et al. 2013 showed that these extremes values of AMO and NAO are associated with the 2009 Pacific El Niño. These results evidence that the SST inter-annual variability in the Gulf of Guinea is also linked with the Pacific inter-annual variabilities as mentioned (Burls et al., 2011).

Furthermore, these strong SSTA observed during the 2008, 2009, 2010 and 2012 years in the NGoG have also been observed in the Atlantic Cold Tongue (ACT) region (Burmeister et al., 2016; Jouanno et al, 2017), so suggesting a link between the variability of the NGoG coastal upwellings and the ACT. Indeed, for example, an extreme cold SST event occurred in the ACT region in boreal summer 2009 (Burmeister et al., 2016) as in the NGoG region. The recent study by Jouanno et al. (2017) indicates that the SST inter-annual variability in the equatorial and coastal upwelling areas is mainly controlled by the ocean dynamics. These 
356

357

authors highlighted that the wind stress inter-annual variability plays a crucial role in SST changes.

This work clearly evidences that the PROPAO network of SST ONSET sensors may be relevant and should be used for i) evaluating satellite and model outputs in the NGoG and ii) accurately studying the coastal upwelling variability along the coast of NGoG. This regional data bank needs to be maintained on the long term and the recording of data deserves to be continued in order to better address the Gulf of Guinea coastal dynamics.

\section{Acknowledgements}

This work was supported by the French Institute for Research and Development (IRD) through the "PROPAO", the "JEAI ALOC-GG" and the "JEAI SAFUME" projects. Authors also acknowledge Clément Assémian (CRO, Abidjan) for his help in data acquisition and treatment. This work is dedicated to Rémy Chuchla, who strongly contributed to the success of the PROPAO network implementation and data acquisition.

\section{Appendix A}

Figure A1 is the same as Figure 5 representing the SST inter-annual anomaly variability without applying the Hanning filter. The SST anomaly derived from the ONSET data is shown here, and it depicts the same patterns as those of the other data sets (Figure A1 a). The SST inter-annual signal displayed by the Figure A1 is the same as those displayed by the Figure 5, even if the amplitude of the anomalies is higher than in the latter.

During the minor upwelling period (JFM), SSTA exhibits low variability at Lagos and Cotonou stations all along 2008, 2009, 2011 and 2012, while in 2010, SSTA shows relatively high variability with values around $1{ }^{\circ} \mathrm{C}$ (Figure A2 a and b). In Takoradi, SSTA displays two warm events in 2008 and 2010 with values less than $0.5^{\circ} \mathrm{C}$ and $1.5^{\circ} \mathrm{C}$ respectively, and two 
380

381

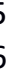

cold events in 2009 and 2012 with values less than $-0.5^{\circ} \mathrm{C}$ and $-1.5^{\circ} \mathrm{C}$, respectively (Figure A2 c). In Sassandra, the pattern displayed is quite the same as in Takoradi (Figure A2 d).The cold event in 2009 is particularly pronounced in data derived from ONSET SST data with SSTA values around $-1.5^{\circ} \mathrm{C}$ while they are close to 0 in the other data sets. In contrast, the cold event in 2012 is practically the same order of magnitude in all data $(-1.7$ to -1$)$.

During the major upwelling period, SSTA displays a weak variability with two moderate warm events in 2008 and 2010 (SSTA $<0.5^{\circ} \mathrm{C}$ ), and also two moderate cold events in 2009 and $2012\left(\mathrm{SSTA}>-0.5^{\circ} \mathrm{C}\right)$ in Nigeria (Figure A2). In Cotonou, we have the same pattern as previously. The cold event in 2009 (SSTA $\sim-0.5^{\circ} \mathrm{C}$ ) and the warm one in 2010 (SSTA 0.5) are stronger than those in Nigeria (Figure A2b). In Ghana, SSTA displays a moderate warming in $2008\left(\mathrm{SSTA}<0.5^{\circ} \mathrm{C}\right)$ and strong warming in 2010 (SSTA $1.5^{\circ} \mathrm{C}$ ). Here also, we have two cooling, a moderate one in 2009 (SSTA $-1^{\circ} \mathrm{C}$ ) and a strong one in 2012 with SSTA $<-1.5^{\circ} \mathrm{C}$. In Côte d'Ivoire, the pattern displayed is quite different from those in Ghana (Figure A2). The warm event is stronger than in Ghana, and the cool event in 2009 is more pronounced with SSTA around $-2.5^{\circ} \mathrm{C}$. 

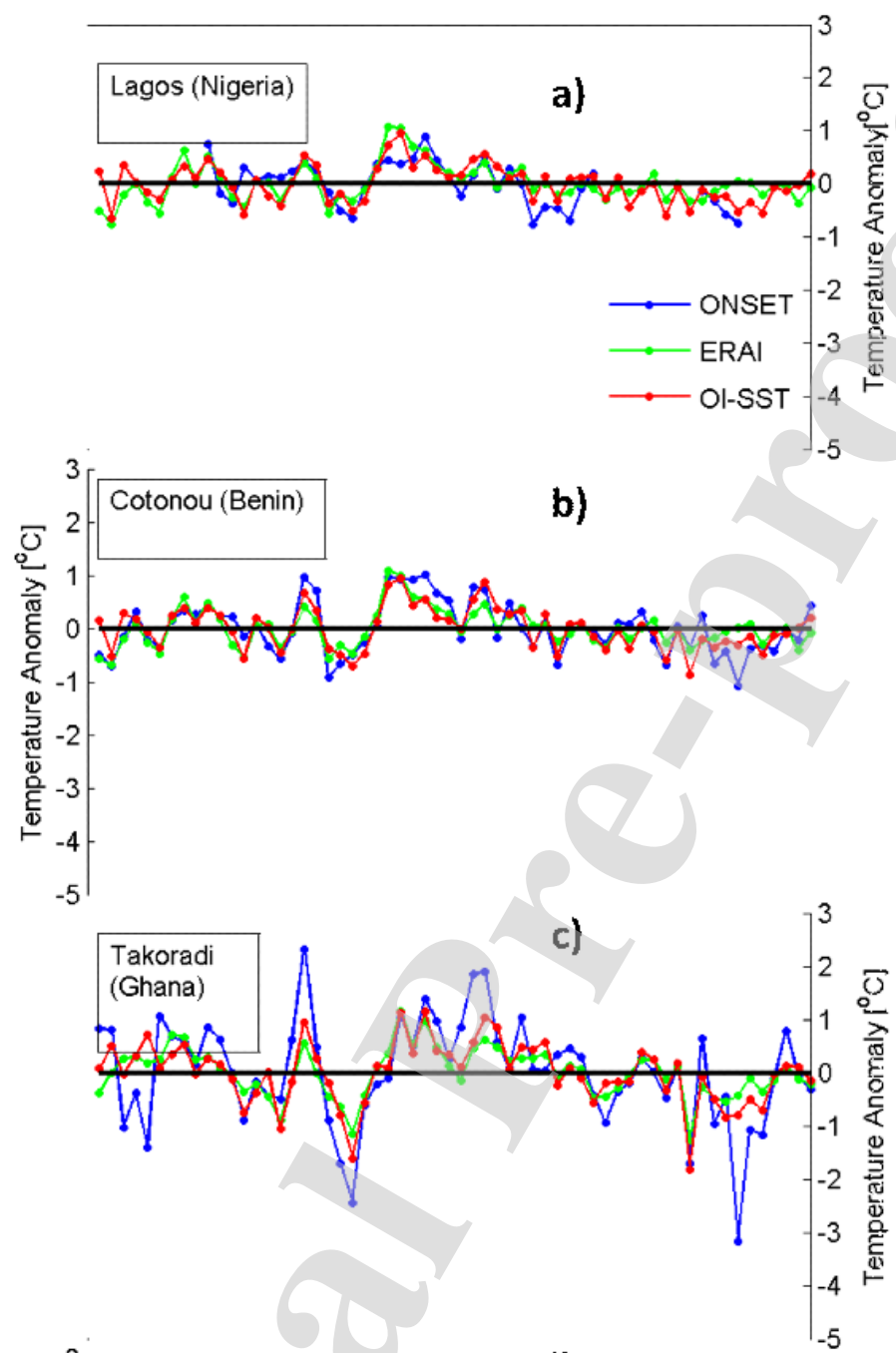

d)

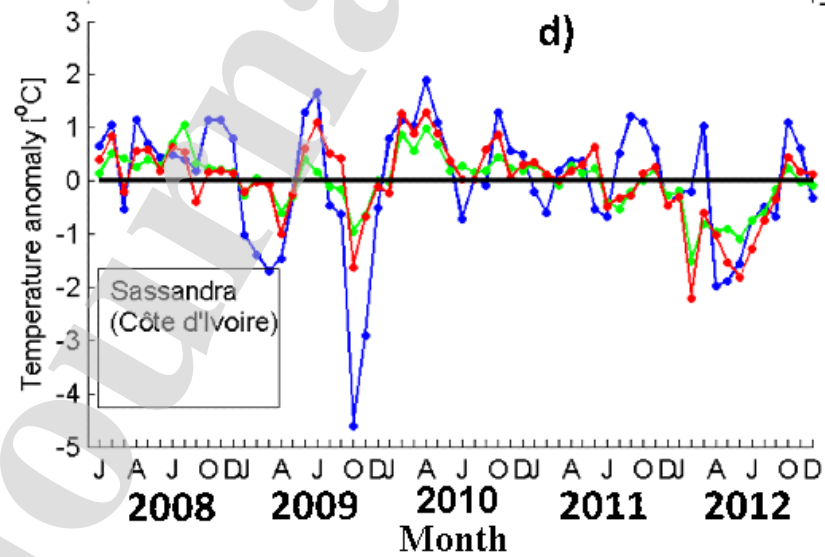

Figure A1: Inter-annual anomalies of SST in the countries of the PROPAO network. The anomalies are based on the monthly mean. 


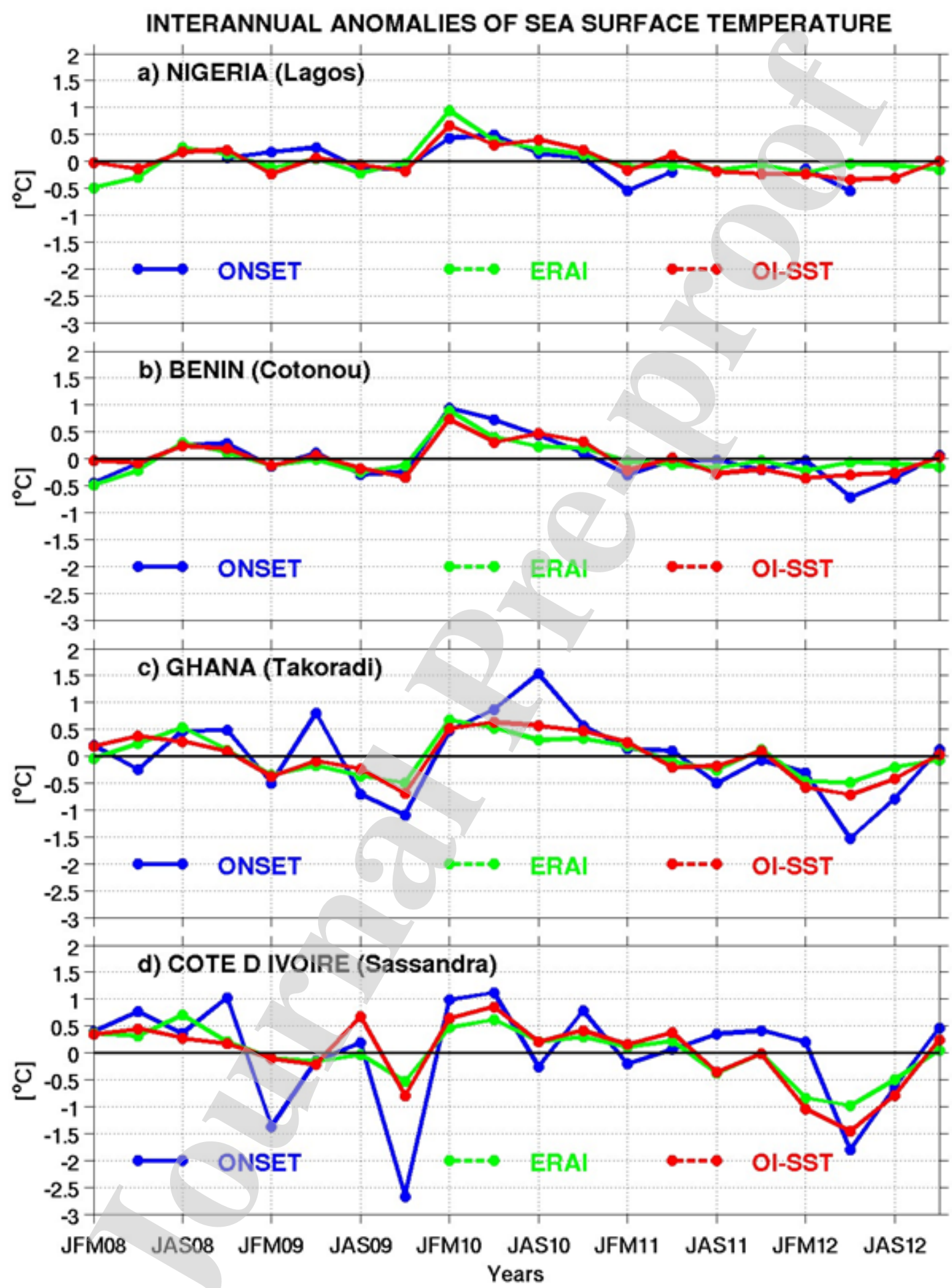

Figure A2 : Trimonthly evolution of the SST Interannual anomaly in the countries of the PROPAO network. 


\section{References}

Alvera-Azcàrate, A., Troupin, C., Barth, A., and Beckers, J-M., 2011. Comparison between satellite and in situ sea surface temperature in the Western Mediterranean Sea, Ocean Dynamics, DOI:10.1007/s10236-011-0403-x.

Arfi, R., Pezennec, O., Cissoko, S., Mensah, M., 1993. Evolution spatio-temporelle d'un indice caractérisant l'intensité de la résurgence ivoiro-ghanéenne. In : Le milieu marin. Environnement et ressources aquatiques de Côte d'Ivoire. Le Loeuf, P., Marchal, E., and Amon Kothias, J.-B. (eds), Orstom, Paris, 112-122.

Awo, F. M., G. Alory., Y. C. Da Allada, T. Delcroix, J. Jouanno, E. Baloitcha, 2018: Sea Surface Salinity signature of the tropical Atlantic interannual climatic modes, J. Geophys. Res.: Oceans, 123. https://doi.org/10.1029/2018JC013837.

Bakun, A., 1978. Guinea Current Upwelling. Nature, 271, 147-150.

Binet, D., Marchal, E., 1993. The large marine ecosystem of shelf areas in the Gulf of Guinea: long-term variability induced by climatic changes. In: Sherman, K., Alexander, L.M., Gold, B.D. (Eds.), Large Marin Ecosystems: Storn, Mitigation and Sustainability. AAAS Publication 92-395, pp. 104-118.

Brandt, P., G. Caniaux, B. Bourlès, A. Lazar, M. Dengler, A. Funk, V. Hormann, H. Giordani, and F. Marin, 2011. Equatorial upper-ocean dynamics and their interaction with the west African monsoon, Atmos. Sci. Let., 12, 24-30, doi:10.1002/as1.287.

Burls, N. J., C. J. Reason, P. P. Penven, and S. G. Philander, 2011. Similarities between the tropical Atlantic seasonal cycle and ENSO: An energetics perspective, J. Geophys. Res., 116, C11,010, doi:10.1029/2011JC007164. 
Burmeister, K., P. Brandt, and J. F. Lubbecke, 2016. Revisiting the cause of the eastern equatorial Atlantic cold event in 2009, J. Geophys. Res. Oceans, 121, 4777-4789, doi:10.1002/2016JC011719.

Carton, J. A., and B. S. Giese, 2008. A reanalysis of ocean climate using Simple Ocean Data Assimilation (SODA), Mon. Weather Rev., 136, 29993017.

Colin, C., 1989. La variabilité dans le Golfe de Guinée: Nouvelles considérations sur les mécanismes d'upwelling. Thèse de Doctorat, Museum d'Histoire Naturelle de Paris, France.

Colin, C., Gallardo Y., Chuchla, R., Cissoko, S., 1993. Environnements climatique et océanographique sur le plateau continental de Côte d'Ivoire. In: Le milieu marin. Environnement et ressources aquatiques de Côte d'Ivoire. Le Loeuf, P., Marchal, E., and Amon Kothias, J.-B. (eds), Orstom, Paris, 75-110.

Debreu, L., P. Marchesiello, P. Penven, and G. Cambon, 2012. Two-way nesting in splitexplicit ocean models: Algorithms, implementation and validation, Ocean Modell., 49$50,1-21$

Dee, D. P., et al., 2011. The ERA-Interim reanalysis: configuration and performance of the data assimilation system. Q. J. R. Meteorol. Soc. 137: 553-597. doi:10.1002/qj.828.

Demarcq, H., and Aman, A., 2002. A multi-Data Approach for Assessing the SpatioTemporal Variability of the Ivorian-Ghanaian Coastal Upwelling: Understanding Pelagic Fish Stock Dynamics. In The Gulf of Guinea Large Marine Ecosystem. J.M McGlade, P. Cury, K.A. Koranteng and N.J Hardman-Mountford (Eds), 83-92.

Djakouré, S., P. Penven, B. Bourlès, J. Veitch and V. Koné, 2017. Coastally trapped eddies in the north of the Gulf of Guinea, J. Geophys. Res. Oceans, 119, doi:10.1002/2014JC010243. 
457

Djakouré S., P. Penven, B. Bourlès, V. Koné and J. Veitch, 2017. Respective roles of theGuinea Current and local winds on the coastal upwelling in the northern Gulf of Guinea, J Phys. Oceanogr., 47, 1367-1387

Fontaine, B. \& S. Janicot, 1992. Wind field coherence and its variations over West Africa, J. Clim., 5, 512-524.

Joyce, T., andC. Corry, 1994. Requirements for WOCE hydrographic program data reporting, WHP Ofice Report 90-1, WOCE Report n67/91, Woods Hole, Mass., USA.

Hardman Mountford, N.J., and McGlade, M., 2003. Seasonal and inter-annual variability of oceanographic processes in the Gulf of Guinea: An investigation using AVHRR sea surface temperature data. International Journal of Remote Sensing, 24:16, 3247-3268.

Jouanno, J., F. Marin, Y. D. Penhoat, J.-M. Molines, and J. Sheinbaum, 2011. Seasonal modes of surface cooling in the Gulf of Guinea. J. Phys. Oceanogr., 41, 14081416,doi:10.1175/JPO-D-11-031.1.

Jouanno, J., O. Hernandez and E. Sanchez-Gomezet, 2017. Equatorial Atlantic inter-annual variability and its relation to dynamic processes. Earth Syst. Dynam., 8, 1061-1069, 2017 https://doi.org/10.5194/esd-8-1061-2017

Koné, V., C. Lett, P. Penven, B. Bourlès, and S. Djakouré, 2017. A biophysical model of S. aurita early-life history in the northern Gulf of Guinea. Progress in Oceanography, 151, doi: 10.1016/j.pocean.2016.10.008, 83-96.

Kouadio, Y., S. Djakouré, A. Aman, K. E. Ali, V. Koné and E. Toualy, 2013. Characterization of the boreal summer upwelling at the northern Coast of the Gulf of Guinea based on the PROPAO in situ measurements network and satellite data. International Journal of Oceanography, doi: 10.1155/2013/816561, 1-11. 
Lamb, P. J., 1972. Large-scale Tropical Atlantic circulation patterns associated with SubSaharan weather anomalies. Tellus, 30, 240-251.

Lamb, P. J. and R. A. Peppler, 1992. Further case study of Tropical Atlantic surface atmospheric and oceanic patterns associated with sub-Saharan drought. J. Climate, 5, 476-488.

Lefèvre, N., Caniaux, G., Janicot, S., and Gueye, A. K., 2013. Increased CO2 outgassing in February-May 2010 in the tropical Atlantic, followingthe 2009 Pacific El Niño, J.Geophys. Res., 118, 1-13, https://doi.org/10.1002/jgrc.20107.

Manyilizu, M., Dufois, F., Penven, P., and Reason, C., 2014. Inter-annual variability of sea surface temperature and circulation in the tropical western Indian Ocean, African Journal of Marine Science, 36 (2), 233-252

Marin, F., G. Caniaux, B. Bourlès, H. Giordani, Y. Gouriou, and E. Key, 2009. Why were sea surface temperature so different in the eastern equatorial Atlantic in June 2005 and 2006?, J. Phys. Ocean., 39, 1416-1431, doi:10.1175/2008JPO4030.1.

Morlière, A., 1970. Les saisons marines devant Abidjan. Doc. Scient. Centre de Rech. Océanogr., Abidjan, 1(2):1:15.

Roy, C., 1995. The Cote d'Ivoire and Ghana coastal upwellings: Dynamics and changes. In Dynamics and Use of Sardinella Resources from Upwelling of Ghana and Ivory Coast,edited by F. X. Bard and K. A. Koranteng (Paris: ORSTOM Editions), pp. 346361.

Saha, S., S. Moorthi, H.-L. Pan, X. Wu, J. Wang, S. Nadiga, P. Tripp, R. Kistler, J. Woollen, D. Behringer, H. Liu, D. Stokes, et al., 2010. The NCEP Climate Forecast System Reanalysis, Bull. Amer. Meteor. Soc., 91 (8), 1015-1057.

Servain, J., G. Caniaux, Y.K. Kouadio, M.J. McPhaden, and M. Araujo, 2014. Recent climatic 
504

trends in the tropical Atlantic, Clim. Dyn., 43, 3071-3089, https://doi.org/10.1007/s00382-014-2168-7.

Shchepetkin, A., and J. McWilliams, 2005. The regional oceanic modelling system (ROMS): A split-explicit, free surface, topography-following-coordinate oceanic model, Ocean Modell., 9, 347-404.

Sohou, Z., B. Bourlès, R. Djiman, A. Aman, R. Folorunsho, A.K. Armah, R. Chuchla, and V. Racapé, PROPAO : a network of coastal temperature autonomous sensors in the north of the Gulf of Guinea, Proceeding of the Colloquium in Physical Oceanography and Applications, Cotonou, Republica of Benin, 7 November 2012, ed. M. H. Hounkonnou and Y. du Penhoat, ISBN 978-99919-1899-0, June 2014.

Toualy, E., G. Stanojevic, K. Kouadio, and A. Aman, 2012. Multi-decadal variability of sea surface temperature in the northern coast of the Gulf of Guinea, Asian J. of Applied Sci., 2012, ISSN 1996-3343.Verstraete, J-M., 1992. The seasonal upwellings in the Gulf of Guinea. Prog. Oceanog., 29, 1-60.

Vizy, E. K., and K. H. Cook, 2001. Mechanisms by which Gulf of Guinea Eastern North Atlantic sea surface temperature can influence African rainfall. J. Climate, 14, 795-821.

Wauthy B., 1983. Introduction à la climatologie du Golfe de Guinée. Océanogr. Trop. 18 (2): 103-138. 
Figures captions

Figure 1: PROPAO network of ONSET thermometers. The blue dots represent the position of the onset thermometers deployed along the coast of Sassandra, Takoradi, Cotonou and Lagos. The red dots represent the corresponding points to the onset position on the ROMS model grid. The green dots represent the corresponding OI-SST points, and the black dots ERAI points.

Figure 2: a) ONSET TIDBIT v2 sensor, b) Sensor Immersion site at the port of Cotonou, C) Interface for reading and retrieving data.

Figure 3: Monthly SST evolution along the coast of the PROPAO network member countries for the years 2008 to 2012 .

Figure 4: Monthly evolution of SST averaged from 2005 to 2008 in the countries of the PROPAO network

Figure. 5: Inter-annual anomalies of the Sea Surface temperature (SST) in the countries of the PROPAO network. To obtain the inter-annual anomalies, the monthly seasonal climatology of SST is removed to the original time series and then we applied a 13 month Hanning filter to smooth the inter-annual signal.

Table 1: Coordinates of the onset stations and the corresponding points on ERAI, OI-SST and ROMS model grids.

\begin{tabular}{|l|c|c|c|c|c|c|c|}
\hline DATA & \multirow{2}{*}{ ONSET } & \multirow{2}{*}{ ERAI } & \multirow{2}{*}{ OI-SST } & \multirow{2}{*}{ ROMS } & \multicolumn{2}{|c|}{$\begin{array}{c}\text { Distance between onset data and } \\
\text { data/model grid point (km) }\end{array}$} \\
\cline { 5 - 8 } & & & & ERAI & OI-SST & ROMS \\
\hline NIGERIA (Lagos) & $\begin{array}{r}3.41^{\circ} \mathrm{E} ; \\
6.42^{\circ} \mathrm{N}\end{array}$ & $\begin{array}{c}3.75^{\circ} \mathrm{E} ; \\
6^{\circ} \mathrm{N}\end{array}$ & $\begin{array}{c}3.37^{\circ} \mathrm{E} ; \\
6.37^{\circ} \mathrm{N}\end{array}$ & $\begin{array}{c}3.40^{\circ} \mathrm{E} ; \\
6.33^{\circ} \mathrm{N}\end{array}$ & 59.94 & 7.10 & 10.06 \\
\hline BENIN (Cotonou) & $\begin{array}{r}2.67^{\circ} \mathrm{E} ; \\
6.52^{\circ} \mathrm{N}\end{array}$ & $\begin{array}{c}3^{\circ} \mathrm{E} ; \\
6^{\circ} \mathrm{N}\end{array}$ & $\begin{array}{c}2.62^{\circ} \mathrm{E} ; \\
6.37^{\circ} \mathrm{N}\end{array}$ & $\begin{array}{c}2.67^{\circ} \mathrm{E} ; \\
6.33^{\circ} \mathrm{N}\end{array}$ & 68.36 & 17.57 & 21.12 \\
\hline
\end{tabular}




\begin{tabular}{|c|c|c|c|c|c|c|c|}
\hline $\begin{array}{l}\text { GHANA } \\
\text { (Takoradi) }\end{array}$ & $\begin{array}{r}1.73^{\circ} \mathrm{W} ; \\
4.88^{\circ} \mathrm{N}\end{array}$ & $\begin{array}{l}1.5^{\circ} \mathrm{W} \\
4.5^{\circ} \mathrm{N}\end{array}$ & $\begin{array}{l}1.62^{\circ} \mathrm{W} ; \\
4.87^{\circ} \mathrm{N}\end{array}$ & $\begin{array}{l}1.73^{\circ} \mathrm{W} \\
4.87^{\circ} \mathrm{E}\end{array}$ & 49.34 & 12.23 & 1.11 \\
\hline $\begin{array}{l}\text { COTE-D'IVOIRE } \\
\text { (Sassandra) }\end{array}$ & $\begin{array}{l}6.08^{\circ} \mathrm{W} ; \\
4.95^{\circ} \mathrm{N}\end{array}$ & $\begin{array}{l}6^{\circ} \mathrm{W} ; \\
4.5^{\circ} \mathrm{N}\end{array}$ & $\begin{array}{l}6.12^{\circ} \mathrm{W} ; \\
4.87^{\circ} \mathrm{N}\end{array}$ & $\begin{array}{l}6.07^{\circ} \mathrm{W} \\
4.87^{\circ} \mathrm{N}\end{array}$ & 50.81 & 9.93 & 8.96 \\
\hline
\end{tabular}

Table 2: Root mean square (RMS) of SST from 2008-2012

\begin{tabular}{|l|c|c|c|c|}
\hline & Lagos & Cotonou & Takoradi & Sassandra \\
\hline ONSET & 28.89 & 28.06 & 26.20 & 25.89 \\
\hline ERAI & 28.10 & 27.98 & 27.35 & 27.29 \\
\hline OI-SST & 27.98 & 27.78 & 26.96 & 26.75 \\
\hline
\end{tabular}

